\title{
Testing the associations between different aspects of seafarers' employment contract and on-board internet access and their job and life satisfaction and health
}

\author{
Ana Slišković and Zvjezdan Penezić
}

Department of Psychology, University of Zadar, Croatia

[Received in February 2016; CrossChecked in February 2016; Accepted in August 2016]

\begin{abstract}
The aim of this study was to test for associations between different aspects of contract and on-board internet access and seafarers' satisfaction and health. Altogether 298 Croatian seafarers, all officers, employed on cargo ships, with a minimum work experience of two years with their current shipping company, participated in an online survey. The questionnaire included sociodemographic items, questions relating to their employment contract and internet access, and measures of job satisfaction, life satisfaction, mental health, and gastrointestinal and cardiovascular symptoms. Their job- and lifesatisfaction levels were higher for shorter duration on board, favourable ratio of work to non-work days, and compliance with the employment contract regarding the changes to work and non-work days. Mental health differed likewise but only in relation to two aspects of the contract: on-board duration and compliance with the contract. The level of gastrointestinal symptoms was lower in cases of shorter on-board duration and compliance with the contract, and in seafarers who have free, unlimited internet access on board. Lower level of cardiovascular symptoms was found in seafarers with free, unlimited internet access on board. Our findings suggest that in promoting satisfaction and health in seafaring, attention should be given to reducing on-board duration, compliance with the contract, and internet accessibility on board.
\end{abstract}

KEY WORDS: compliance with contract; gastrointestinal and cardiovascular symptoms; isolated working environment; mental health; on-board duration; ratio of work to non-work days

Seafarers face many stressors, risks and challenges (1, 2) which may have impact on their physical and mental health. However, studies relating to health, morbidity, and mortality in seafarers [e.g. gastrointestinal disease mortality (3); cardiovascular disease mortality (4)] are often confounded by the "healthy worker effect", which is explained by self-selection and adaptation: seafarers who cannot adapt to work on board, as well as those who suffer from the effects of occupational stressors, leave the occupation. Still, Oldenburg et al. (5) show that, even if this effect is considered, it appears that cardiac risk factors occur slightly more frequently in seafarers than in the general population. Furthermore, data on suicides in seafarers (6) show that the mental health of seafarers in many cases continues to be very poor and often fatal. Therefore, studies on the role of different work characteristics in the explanation of physical and mental health, as well as the satisfaction of seafarers, are very important, from both the individual and organisational perspectives.

One inherent characteristic of seafaring is living and working in an isolated confined environment, away from home, with no opportunity to leave the workplace for a specified time period, which may act as a chronic work

Correspondence to: Ana Slišković, PhD Department of Psychology, University of Zadar, Obala kralja Petra Krešimira IV, 2, 23000 Zadar, Croatia, E-mail: aslavic@unizd.hr stressor (7). Indeed, long-term separation from home and family and social isolation on board are among the most frequently cited psychosocial stressors in seafaring $(1,6$, 8-11). In this article we focus on two important work characteristics: seafarer's employment contract and internet access, which were shown to be important in describing Croatian seafarers' (dis)satisfaction (12). The study (12) shows that dissatisfaction with the contract stems from three aspects: 1) length of time on board, 2) unfavourable ratio of workdays to days off (e.g. 4-2 rather than 3-3), and 3) non-compliance with the contract regarding the stay on board and at home (irregularity of shifts). Even those participants with shorter duration on board (e.g. 2 months) and favourable contracts in terms of the balance between workdays and days off (e.g. 3-3 months), when describing sources of job dissatisfaction, see irregularity as one of those important negative work characteristics which "markedly violate leisure time at home, disable quality rest and family and social obligations, and also negatively affect financial planning". Unavailability and price of the internet was often cited as a source of dissatisfaction. Conversely, free internet access on board was described by many participants as one of the rare sources of satisfaction on board.

Since this study was descriptive and qualitative, we performed a quantitative study to test whether three aspects 
of the contract - (1) duration on board, 2) ratio between working and non-working days, and 3) compliance with the contract regarding the changes in working and free time - as well as the access to free internet on board, have significant effects on job satisfaction and life satisfaction. On the basis of the qualitative study we assumed that satisfaction with work and life would be higher in seafarers with shorter durations on board, favourable ratios between work and non-work days, regular shifts, and free access to the internet on board. Being physically away from home and family and living in an isolated shipping environment may lead to anxiety and depression $(6,8,9)$. Therefore, we tested the effects of different aspects of the contract and internet access on mental health, assuming that better mental health would be found in seafarers with shorter and favourable contracts, regular shifts, and access to the internet on board. Finally, our objective was also to test these effects on physical health, where we focused on gastrointestinal and cardiovascular symptoms, since it has been shown that cardiovascular disease and gastrointestinal disease are among the major causes of morbidity and death in seafarers (13). Morbidity in seafarers is also explained by lifestyle factors, especially by smoking, alcohol use, malnutrition (unbalanced, high-fat diet), and lack of exercise on board $(14,15)$. Furthermore, work on board is organised in shifts (watch system), and disturbance of circadian rhythms imposed by shift work, especially night work, is recognised as an important factor in the development of gastrointestinal and cardiovascular diseases (16). We hypothesised, therefore, that levels of gastrointestinal and cardiovascular symptoms might also be affected by negative characteristics of the contract, such as duration of on-board stay, unfavourable ratio between working and off days, and irregularity of shifts. Furthermore, considering the importance of cyberspace communication on board with partners, family, and friends $(12,17,18)$ for satisfaction, turnover, and retention in seafarers, we also hypothesised that non-accessibility of the internet on board may act as a chronic stressor which may lead to somatic stress reactions (19), i.e. negatively affect seafarers' health.

In spite of the importance of accessibility of the internet on board in promoting seafarers' satisfaction and retention, there is no data about its effects on the mental and physical health of seafarers. Furthermore, to our knowledge, there is no available study which has tested the effects of different aspects of seafarer's employment contract on satisfaction and health, while controlling the important characteristics which may confound these effects, such as nation and rank. Previous studies have shown that the perception of stressors on board, self-rated health measures, and psychological well-being and satisfaction, largely vary with culture or country, rank and profession, and the type of vessel $(1,20$ 22), largely because of cultural/rank differences in staying on board. Therefore, testing the impact of the contract on different outcome measures in a specific national group of Croatian seafarers may be an advantage of this study. In order to achieve further homogeneity of the sample, we focused only on officer ranks, employed in international cargo shipping. In doing so, we avoided the masking of the effects of the rank and type of maritime activity. We considered cargo ships a qualitatively different working environment compared to passenger or offshore vessels. Finally, given the labour fluctuations in seafaring, in order to examine the tested effects of work characteristics which differ among shipping companies, we limited our sample to those seafarers who had been employed at the same shipping company for a minimum of two years.

\section{METHODS}

\section{Participants}

The study included a total of 298 Croatian seafarers employed on cargo ships. The average age was 39.16 years $(\mathrm{SD}=9.98)$, length of service in the maritime sector 15.09 years $(\mathrm{SD}=9.71)$, and length of service with the current company $11.57(\mathrm{SD}=10.42)$.

The study included only higher-ranking officers (no ratings). Numbers and percentages of education level and job description are given in Table 1 , as well as other relevant demographic characteristics. The largest numbers of participants worked on LNG and LPG ships, oil tankers, and oil products and container ships, while the rest of the sample worked on other cargo ships (see Table 1).

\section{Procedure and Ethics}

In order to reach Croatian seafarers employed on cargo ships, we contacted various organisations and groups which helped us with the advertising of the study on their webpages and/or forwarding e-mail invitations to seafarers relating to their organisations (Croatian shipping companies, Croatian agencies for seafarers, the Seafarers Union of Croatia, educational institutions in Croatia involved in the training of seafarers, the Croatian web page Pomorac.net, LinkedIn groups of Croatian seafarers, etc.). Response-rate data is missing from our study for two reasons: (1) use of non-probabilistic sampling procedure (not possible to calculate the number of seafarers who got forwarded e-mail invitations from their company/agency/colleague or who saw the advertisement of the study on the web page of their agency/union etc.), (2) the lack of a population frame for Croatian officers on international cargo ships (employed in the current shipping organisation for a minimum of two years). The latest statistical data on Croatian seafarers show that Croatian seafarers make up approximately one percent of the total number of seafarers (23). In Croatia there are approximately 20,000 seafarers, of which 15,184 take part in international sea shipping (23). On the basis of national statistics (official statistics of seafarers in international shipping, by the Ministry of Maritime Affairs, Transport, and Infrastructure) for 2014, of which $58 \%$ are in higher 
Table 1 Demographic characteristics

\begin{tabular}{|c|c|c|c|c|}
\hline & Mean & SD & Min & Max \\
\hline Age & 39.16 & 9.98 & 21 & 65 \\
\hline Service length $-\mathrm{MS}^{1}$ & 15.09 & 9.71 & 2 & 44 \\
\hline \multirow[t]{2}{*}{ Service length $-\mathrm{WO}^{2}$} & 11.57 & 10.42 & 2 & 44 \\
\hline & & & $\mathbf{N}$ & $\%$ \\
\hline \multirow{3}{*}{ Education level } & High school & & 78 & 26.17 \\
\hline & College & & 147 & 49.32 \\
\hline & University & & 73 & 24.50 \\
\hline \multirow{4}{*}{ Job description } & Engine officer & & 71 & 23.83 \\
\hline & Deck officer & & 120 & 40.27 \\
\hline & Chief engineer & & 40 & 13.42 \\
\hline & Commander & & 67 & 22.48 \\
\hline \multirow{8}{*}{ Type of ship/cargo } & $\mathrm{LNG}^{3}$ and $\mathrm{LPG}^{4}$ & & 113 & 37.92 \\
\hline & Tankers (oil and & & 74 & 24.83 \\
\hline & Containers & & 61 & 20.47 \\
\hline & Bulk cargo & & 20 & 6.71 \\
\hline & Chemicals & & 13 & 4.36 \\
\hline & Ro-Ro (cargo on & & 9 & 3.02 \\
\hline & General cargo & & 5 & 1.68 \\
\hline & Combined cargo & & 3 & 1.01 \\
\hline \multirow{2}{*}{ Shipping organisation } & Croatian & & 21 & 7.05 \\
\hline & Foreign & & 277 & 92.95 \\
\hline \multirow{2}{*}{ Marital status } & Single & & 55 & 18.46 \\
\hline & Married / in dom & & 243 & 81.54 \\
\hline \multirow{4}{*}{ Number of children } & 0 & & 94 & 31.54 \\
\hline & 1 & & 69 & 23.15 \\
\hline & 2 & & 108 & 36.24 \\
\hline & 3 or more & & 27 & 9.06 \\
\hline \multirow{2}{*}{ Current location } & Ship & & 110 & 36.91 \\
\hline & Home & & 188 & 63.09 \\
\hline
\end{tabular}

Note: ${ }^{1}=$ length of service in maritime sector $(M S) ;{ }^{2}=$ length of service in current work organisation $($ WO $) ;{ }^{3}=$ liquefied natural gas; ${ }^{4}=$ liquefied petroleum gas

ranks (commanders, chief engineers, engine officers, and deck officers), our sample amounts to $3.4 \%$ of the population of Croatian officers in international shipping (including foreign and national companies). However, there is no precise data for cargo ships only. Data on the Croatian maritime market (24) show that Croatian seafarers in international shipping were employed on tankers (45\%), dry cargo ships (20\%), LNG (15\%), offshore (10\%) and passenger ships (10\%). Overall, one of the disadvantages of our study is the limited generalisability of its results, which stems from the sample's questionable representativeness of the population of Croatian officers on cargo ships; therefore further studies on representative samples are strongly recommended. However, considering the fact that seafarers are a hard-to-reach population, and that the use of a non-probabilistic sample procedure increases confidence in anonymity for the participants, we consider the sample obtained to be good enough for investigating the tested effects.

The study was previously approved by the Ethics Committee of the Department of Psychology, University of Zadar. All procedures performed in the study involving human participants were in accordance with the ethical standards of the institutional and/or national research committee and with the 1975 Helsinki declaration and its later amendments. The study was conducted in 2014 using an online survey. At the time of participation, about $63 \%$ of participants were at home, and about $37 \%$ were at sea. Invitations to participate in the study included ethical requirements for informed consent, voluntary participation, and confidentiality of data and anonymity of participants. Data collected did not include any names, contact details or names of the shipping companies in which participants were employed. Contact details of researchers were 
provided, and participants could contact a researcher with questions or comments. Feedback about the results of the study was guaranteed to participants on request.

\section{Materials}

The first part of the questionnaire (see Annex for whole questionnaire) was created by the authors and included basic demographic items and questions related to the contract and internet access. Demographic questions included: gender, age, years of service, education level, job description, type of cargo ship, marital status, children, and current location (all shown in Table 1 - except gender, since all participants were men).

Three questions regarding the contract were asked: (1) number of months on board according to the contract, (2) number of months at home according to the contract, and (3) compliance with the contract regarding the changes to ship and home periods. For the first two questions, the possible answers were: $1,2,3,4,5,6$, and more than 6 . Numbers and percentages for exact durations of ship-home periods are given in Table 2. However, considering the huge range of answers, which were also unequally distributed, and in order to respond to our research objective, we used somewhat different variables: length of duration on board (divided into 2, 3, 4, and more than 4 months) and the ratio between ship and home period (operationalised as favourable and non-favourable) (see Table 3). For

Table 2 Ship-home duration in months according to the contract

\begin{tabular}{|c|c|c|}
\hline $\begin{array}{l}\text { Ship-home time } \\
\text { (months) }\end{array}$ & $\mathbf{N}$ & $\%$ \\
\hline $2-2$ & 37 & 12.42 \\
\hline $3-3$ & 113 & 37.92 \\
\hline 4-4 & 31 & 10.40 \\
\hline $5-5$ & 1 & 0.34 \\
\hline $6-6$ & 6 & 2.01 \\
\hline $2-1$ & 1 & 0.34 \\
\hline $3-1$ & 1 & 0.34 \\
\hline $3-2$ & 11 & 3.69 \\
\hline $4-2$ & 45 & 15.10 \\
\hline $4-3$ & 29 & 9.73 \\
\hline $5-2$ & 1 & 0.34 \\
\hline $5-3$ & 7 & 2.35 \\
\hline $6-2$ & 1 & 0.34 \\
\hline $6-3$ & 3 & 1.01 \\
\hline $6-4$ & 1 & 0.34 \\
\hline $6-5$ & 3 & 1.00 \\
\hline$>6-1$ & 1 & 0.34 \\
\hline$>6-3$ & 1 & 0.34 \\
\hline$>6-4$ & 3 & 1.00 \\
\hline$>6-5$ & 1 & 0.34 \\
\hline$>6-6$ & 1 & 0.34 \\
\hline
\end{tabular}

compliance with the contract, four categories of answers were provided: changes to the periods on board and at home are $1=$ always in compliance with the contract $(\mathrm{N}=39)$, $2=$ mostly in compliance with contract $(\mathrm{N}=193), 3=$ mostly not in compliance with the contract $(\mathrm{N}=50), 4=$ never in compliance with the contract $(\mathrm{N}=16)$. In further analysis we merged the categories always and mostly into one and named it "regular shifts", and mostly not and never into another named "irregular shifts".

The question relating to internet access was »having free and unlimited access to the internet on board «, and the possible answers were dichotomous: yes and no.

Job satisfaction was assessed with the scale of Overall Job Satisfaction (25), consisting of five statements to which participants expressed their agreement on a scale from 1 to $5(1=$ strongly disagree; $5=$ strongly agree $)$. Examples of items: "I feel fairly satisfied with my present job", "Each day at work seems like it will never end" (reverse-coded item).

The Satisfaction with Life Scale (26-28) was used as a known, valid, and reliable measure of global cognitive judgments of one's life satisfaction. It consists of five items (e.g. "In most ways my life is close to my ideal", "If I could live my life over, I would change almost nothing"). The version with a 5-point scale (from 1=strongly disagree to $5=$ strongly agree) of answers (29) was used.

Mental health was measured by the five-item version of the Mental Health Inventory, MHI-5 (30), which assesses the frequency of five domains of mental health on a six-point scale $(1=$ all the time to $6=$ never $)$. These domains include anxiety ("How much of the time have you been a very nervous or anxious person?"), general positive affect ("How much of the time have you felt calm or peaceful?", "How much of the time have you been a happy person?"), depression ("How much of the time have you felt downhearted or blue?"), and behavioural/emotional control ("How often have you felt so down in the dumps that nothing could cheer you up?"). The MHI-5 is considered a brief measure of depressive symptoms and feelings of anxiety. The two general positive-affect items are reversecoded and summed with the other three items to give a composite score on the scale, with higher scores indicating better overall mental health.

Gastrointestinal (digestive) symptoms and cardiovascular symptoms were measured by two subscales of the Physical Health Questionnaire section of the Shiftwork Survey, which was developed as a shorter version of the Standard Shiftwork Index (31). Each subscale consists of eight questions, with response options ranging from 1 = almost never to $4=$ almost always. Examples of items: "How often do you suffer from constipation or diarrhoea?", "How often is your appetite disturbed?" (gastrointestinal symptoms); "Have you ever been aware of your heart beating irregularly?", "Do you suffer from shortness of breath when climbing the stairs normally?" (cardiovascular symptoms). A total score is computed for 
Table 3 Descriptive statistics for different aspects of contract and access to free, unlimited internet on board

\begin{tabular}{llcc} 
& & $\mathbf{N}$ & $\mathbf{\%}$ \\
\hline \multirow{4}{*}{ Time on board } & 2 months & 38 & 12.75 \\
\cline { 2 - 4 } & 3 months & 125 & 41.49 \\
\cline { 2 - 4 } & 4 months & 106 & 35.57 \\
\cline { 2 - 4 } $\begin{array}{l}\text { Ratio between working and } \\
\text { free days }\end{array}$ & Favourable $(=)$ & 29 & 9.73 \\
\cline { 2 - 4 } Compliance with contract & Unfavourable $(\neq)$ & 188 & 63.09 \\
\hline \multirow{2}{*}{\begin{tabular}{l} 
Free unlimited internet access \\
\cline { 2 - 4 }
\end{tabular}} & Regular shifts & 110 & 36.91 \\
\cline { 2 - 4 } & Irregular shifts & 232 & 77.85 \\
\cline { 2 - 4 } & Yes & 66 & 22.15 \\
\hline
\end{tabular}

each scale by summing the individual scores, and a higher score on each scale is associated with poorer physical health.

All the scales used had good internal consistency in our sample, with alpha coefficients ranging from 0.82 to 0.90 (See Table 4 for a summary).

\section{Statistics}

In order to test the effects of different aspects of contract and internet access by parametric statistical analysis (ANOVA), we first checked the normality of our scale data. Visual inspection of histograms and skewness and kurtosis measures (Table 4) show that job- and life-satisfaction distributions and mental health are moderately negatively skewed. Mental-health distribution was also leptokurtic. The distributions of gastrointestinal and, especially, cardiovascular symptoms were positively skewed. These results are expected, since our participants are derived from a healthy population of seafarers who are subjected to regular medical examination. Moreover, one-way ANOVA is considered a robust test against the normality assumption, i.e. tolerates violations to its normality assumption rather well. Schmider et al. (32) showed that type error $\alpha$ and type error $\beta$ remain constant under violation. However, in the case of the highly skewed distribution of cardiovascular symptoms, we transformed this variable by logarithmic method using $\log (10)(33,34)$ in order to apply ANOVAs.

We tested the effects of (1) the contract duration, (2) ratio between work and non-work days, (3) compliance with the contract, and (4) internet access on five dependent measures: job satisfaction, life satisfaction, mental health, gastrointestinal symptoms, and cardiovascular symptoms$\log (10)$ (Tables 5-9). Before applying ANOVAs, we checked the assumption of homogeneity of variance using Levene's test, and in cases of violation of this assumption we used Welch's test instead of ANOVA. Furthermore, for duration effect we used a post-hoc test: Tukey after ANOVAs and Games Howell in cases of assumption of unequal variances.

\section{RESULTS}

Time on board had a significant effect on job satisfaction (Table 5), with the highest level of job satisfaction in the shortest duration on board (two months). The Tukey posthoc test indicated that differences among the four categories

Table 4 Descriptive statistics for job satisfaction, life satisfaction, mental health, gastrointestinal symptoms, and cardiovascular symptoms

\begin{tabular}{|c|c|c|c|c|c|c|c|c|}
\hline Scale (number of items) & $\begin{array}{c}\text { Cronbach } \\
\text { alpha }\end{array}$ & Mean & SD & Median & $\begin{array}{c}\text { Theoretical } \\
\text { range }\end{array}$ & Range & $\begin{array}{c}\text { Skewness } \\
\text { (SE) }\end{array}$ & $\begin{array}{c}\text { Kurtosis } \\
\text { (SE) }\end{array}$ \\
\hline Job satisfaction (5) & .85 & 16.62 & 4.41 & 17 & $5-25$ & $5-25$ & $\begin{array}{l}-0.56 \\
(0.14)\end{array}$ & $\begin{array}{l}-0.00 \\
(0.28)\end{array}$ \\
\hline Life satisfaction (5) & .85 & 15.23 & 4.22 & 16 & $5-25$ & $5-25$ & $\begin{array}{l}-0.29 \\
(0.14)\end{array}$ & $\begin{array}{l}-0.34 \\
(0.28)\end{array}$ \\
\hline Mental Health (5) & .82 & 22.55 & 3.36 & 23 & $5-30$ & $10-30$ & $\begin{array}{l}-0.55 \\
(0.14)\end{array}$ & $\begin{array}{c}0.75 \\
(0.28)\end{array}$ \\
\hline $\begin{array}{l}\text { Gastrointestinal } \\
\text { symptoms (8) }\end{array}$ & .90 & 13.39 & 4.53 & 13 & $8-32$ & $8-30$ & $\begin{array}{c}0.79 \\
(0.14) \\
\end{array}$ & $\begin{array}{c}0.20 \\
(0.28) \\
\end{array}$ \\
\hline $\begin{array}{l}\text { Cardiovascular } \\
\text { symptoms (8) }\end{array}$ & .89 & 11.05 & 3.51 & 10 & $8-32$ & $8-25$ & $\begin{array}{c}1.16 \\
(0.14) \\
\end{array}$ & $\begin{array}{c}0.55 \\
(0.28)\end{array}$ \\
\hline $\begin{array}{l}\text { Cardiovascular } \\
\text { symptoms }^{t}\end{array}$ & & 1.02 & 0.12 & 1 & & $0.9-1.4$ & $\begin{array}{c}0.76 \\
(0.14)\end{array}$ & $\begin{array}{l}-0.60 \\
(0.28)\end{array}$ \\
\hline
\end{tabular}

Note: ${ }^{t}$ - transformed as $\log (10)$ 
Table 5 Effects of different aspects of contract and internet access on job satisfaction

\begin{tabular}{|c|c|c|c|c|c|c|}
\hline & & Mean & SD & df1 / df2 & Levene (p) & $\mathbf{F}(\mathbf{p})$ \\
\hline \multirow{4}{*}{$\begin{array}{l}\text { Time on board } \\
\text { (months) }\end{array}$} & 2 & 18.12 & 4.03 & \multirow{4}{*}{$3 / 294$} & \multirow{4}{*}{$0.99(0.399)$} & \multirow{4}{*}{$\begin{array}{c}3.42 \\
(0.018)^{*}\end{array}$} \\
\hline & 3 & 16.84 & 4.10 & & & \\
\hline & 4 & 15.68 & 4.74 & & & \\
\hline & $>4$ & 17.19 & 4.43 & & & \\
\hline \multirow{2}{*}{$\begin{array}{l}\text { Ratio between working and free } \\
\text { days }\end{array}$} & Favourable (=) & 17.20 & 4.21 & \multirow{2}{*}{$1 / 296$} & \multirow{2}{*}{$0.53(0.466)$} & \multirow{2}{*}{$\begin{array}{c}9.05 \\
(0.003)^{* *}\end{array}$} \\
\hline & Unfavourable $(\neq)$ & 15.63 & 4.59 & & & \\
\hline \multirow{2}{*}{ Compliance with the contract } & Regular shifts & 17.12 & 4.29 & \multirow{2}{*}{$1 / 296$} & \multirow{2}{*}{$0.46(0.498)$} & \multirow{2}{*}{$\begin{array}{c}13.92 \\
(0.000)^{* * * *}\end{array}$} \\
\hline & Irregular shifts & 14.87 & 4.43 & & & \\
\hline \multirow{2}{*}{ Free unlimited internet access } & No & 16.50 & 4.18 & \multirow{2}{*}{$1 / 296$} & \multirow{2}{*}{$1.86(0.174)$} & \multirow{2}{*}{$\begin{array}{c}0.19 \\
(0.661)\end{array}$} \\
\hline & Yes & 16.72 & 0.661 & & & \\
\hline
\end{tabular}

Note: ${ }^{*} p<0.05 ; * * p<0.01 ; * * * p<0.001$

of on-board duration were significant only between two and four months $(\mathrm{p}<0.05)$. Job satisfaction also differed regarding the other two aspects of the contract. It was higher in the favourable ratio between working and free days, compared to the unfavourable, and in regular shifts, compared to irregular shifts.

All three aspects of the contract had a significant effect on life satisfaction (Table 6). Life satisfaction was, on average, higher in seafarers with shorter on-board duration, favourable ratio of working and free days, and regular shifts. The Games Howell post-hoc test showed that the category of the shortest duration (two months) differed significantly from all other duration categories $(p<0.01)$. Contrary to expectation, access to the internet did not have an effect on either satisfaction measure (Tables 5 and 6), but in the case of life satisfaction the level of significance was rather close to 0.05 .

Mental health significantly differed with regard to duration of time on board and compliance with the contract, with higher levels in the shortest on-board duration and contract compliance (Table 7). Mental-health level was the highest in the shortest on-board duration (two months), and Table 6 Effects of different aspects of contract and internet access on life satisfaction

\begin{tabular}{|c|c|c|c|c|c|c|c|}
\hline & & Mean & SD & df1 / df2 & Levene (p) & $\mathbf{F}(\mathbf{p})$ & Welch \\
\hline \multirow{4}{*}{$\begin{array}{l}\text { Time on board } \\
\text { (months) }\end{array}$} & 2 & 17.68 & 3.02 & \multirow{4}{*}{$3 / 294$} & \multirow{4}{*}{$\begin{array}{c}2.77 \\
(0.042)^{*}\end{array}$} & & \multirow{4}{*}{$\begin{array}{c}8.84 \\
(0.000)^{* * *}\end{array}$} \\
\hline & 3 & 15.27 & 4.06 & & & & \\
\hline & 4 & 14.53 & 4.41 & & & & \\
\hline & $>4$ & 14.45 & 4.51 & & & & \\
\hline \multirow{2}{*}{$\begin{array}{l}\text { Ratio between } \\
\text { working and free } \\
\text { days }\end{array}$} & Favourable (=) & 15.69 & 4.18 & \multirow{2}{*}{$1 / 296$} & \multirow{2}{*}{$\begin{array}{c}0.02 \\
(0.876)\end{array}$} & \multirow{2}{*}{$\begin{array}{c}6.15 \\
(0.014)^{*}\end{array}$} & \\
\hline & Unfavourable $(\neq)$ & 14.45 & 4.20 & & & & \\
\hline \multirow{2}{*}{$\begin{array}{l}\text { Compliance with } \\
\text { contract }\end{array}$} & Regular shifts & 15.77 & 3.96 & \multirow{2}{*}{$1 / 296$} & \multirow{2}{*}{$\begin{array}{c}5.46 \\
(0.020)^{*}\end{array}$} & & \multirow{2}{*}{$\begin{array}{c}15.49 \\
(0.000)^{* * *}\end{array}$} \\
\hline & Irregular shifts & 13.33 & 4.57 & & & & \\
\hline \multirow{2}{*}{$\begin{array}{l}\text { Free unlimited } \\
\text { internet access }\end{array}$} & No & 14.72 & 4.26 & \multirow{2}{*}{$1 / 296$} & \multirow{2}{*}{$\begin{array}{c}0.334 \\
(0.564)\end{array}$} & \multirow{2}{*}{$\begin{array}{c}3.60 \\
(0.060)\end{array}$} & \\
\hline & Yes & 15.65 & 4.16 & & & & \\
\hline
\end{tabular}


Table 7 Effects of different aspects of contract and internet access on mental health

\begin{tabular}{|c|c|c|c|c|c|c|c|}
\hline & & Mean & SD & df1 / df2 & Levene (p) & $F(p)$ & Welch (p) \\
\hline \multirow{4}{*}{$\begin{array}{l}\text { Time on board } \\
\text { (months) }\end{array}$} & 2 & 24.11 & 2.32 & \multirow{4}{*}{$3 / 294$} & \multirow{4}{*}{$\begin{array}{c}3.33 \\
(0.020)\end{array}$} & & \multirow{4}{*}{$\begin{array}{c}5.76 \\
(0.001)^{* *}\end{array}$} \\
\hline & 3 & 22.13 & 3.58 & & & & \\
\hline & 4 & 22.52 & 3.38 & & & & \\
\hline & $>4$ & 22.45 & 3.00 & & & & \\
\hline \multirow{2}{*}{$\begin{array}{l}\text { Ratio between working } \\
\text { and free days }\end{array}$} & Favourable (=) & 22.68 & 3.26 & \multirow{2}{*}{$1 / 296$} & \multirow{2}{*}{$\begin{array}{c}2.56 \\
(0.111)\end{array}$} & \multirow{2}{*}{$\begin{array}{c}0.77 \\
(0.381)\end{array}$} & \\
\hline & Unfavourable $(\neq)$ & 22.33 & 3.53 & & & & \\
\hline \multirow{2}{*}{$\begin{array}{l}\text { Compliance with the } \\
\text { contract }\end{array}$} & Regular shifts & 22.83 & 3.11 & \multirow{2}{*}{$1 / 296$} & \multirow{2}{*}{$\begin{array}{c}6.67 \\
(0.010)^{*}\end{array}$} & & \multirow{2}{*}{$\begin{array}{c}5.74 \\
(0.019)^{*}\end{array}$} \\
\hline & Irregular shifts & 21.56 & 3.98 & & & & \\
\hline \multirow{2}{*}{$\begin{array}{l}\text { Free unlimited internet } \\
\text { access }\end{array}$} & No & 22.21 & 3.22 & \multirow{2}{*}{$1 / 296$} & \multirow{2}{*}{$0.21(.648)$} & \multirow{2}{*}{$\begin{array}{l}2.417 \\
(.121)\end{array}$} & \\
\hline & Yes & 22.82 & 3.45 & & & & \\
\hline
\end{tabular}

Note: ${ }^{*} p<.05 ; * * p<.01$

this level differed significantly, according to the Games Howell post-hoc test, from that of three months $(\mathrm{p}<0.01)$ and four months $(\mathrm{p}<0.05)$. Neither the ratio between working and free days nor access to the internet had a significant effect on mental health (Table 7).

Levels of gastrointestinal symptoms (Table 8) were significantly lower in shorter on-board duration (The Games Howell post-hoc test indicated a difference only between two and four months, $\mathrm{p}<0.05$ ), and in seafarers with access to free and unlimited internet on board, compared to those without it. The ratio between working and free days did not have an effect on gastrointestinal symptoms, while the effect of compliance with the contract was close to significance $(\mathrm{p}=0.051)$.

Of the four tested effects, only the internet access had a significant effect on cardiovascular symptoms (Table 9), with a higher level of symptoms in seafarers who did not have free, unlimited access to the internet on board. Since a transformed variable of cardiovascular symptoms was used, we checked the transformed and original means of the two categories of the internet access to be sure that the direction of difference was the same (33).

Table 8 Effects of different aspects of the employment contract and internet access on gastrointestinal symptoms

\begin{tabular}{|c|c|c|c|c|c|c|c|}
\hline & & Mean & SD & df1 / df2 & Levene (p) & $F(p)$ & Welch (p) \\
\hline \multirow{4}{*}{$\begin{array}{l}\text { Time on board } \\
\text { (months) }\end{array}$} & 2 & 12.05 & 3.07 & \multirow{4}{*}{$3 / 294$} & \multirow{4}{*}{$\begin{array}{c}6.67 \\
(0.000)^{* * *}\end{array}$} & & \multirow{4}{*}{$\begin{array}{c}3.39 \\
(0.021)^{*}\end{array}$} \\
\hline & 3 & 13.71 & 4.85 & & & & \\
\hline & 4 & 13.00 & 4.06 & & & & \\
\hline & $>4$ & 15.17 & 5.71 & & & & \\
\hline \multirow{2}{*}{$\begin{array}{l}\text { Ratio between } \\
\text { working and free } \\
\text { days }\end{array}$} & Favourable (=) & 13.39 & 4.54 & \multirow{2}{*}{$1 / 296$} & \multirow{2}{*}{$\begin{array}{c}0.468 \\
(0.494)\end{array}$} & \multirow{2}{*}{$\begin{array}{c}0.00 \\
(0.996)\end{array}$} & \\
\hline & Unfavourable $(\neq)$ & 13.39 & 4.53 & & & & \\
\hline \multirow{2}{*}{$\begin{array}{l}\text { Compliance with the } \\
\text { contract }\end{array}$} & Regular shifts & 13.11 & 4.45 & \multirow{2}{*}{$1 / 296$} & \multirow{2}{*}{$0.90(0.344)$} & \multirow{2}{*}{$\begin{array}{c}3.83 \\
(0.050)\end{array}$} & \\
\hline & Irregular shifts & 14.35 & 4.72 & & & & \\
\hline \multirow{2}{*}{$\begin{array}{l}\text { Free unlimited } \\
\text { internet access }\end{array}$} & No & 14.13 & 4.85 & \multirow{2}{*}{$1 / 296$} & \multirow{2}{*}{$3.53(0.061)$} & \multirow{2}{*}{$\begin{array}{c}6.71 \\
(0.010)^{*}\end{array}$} & \\
\hline & Yes & 12.78 & 4.18 & & & & \\
\hline
\end{tabular}

Note: ${ }^{*} p<.05 ; * * * p<.001$ 


\section{DISCUSSION}

The results of this study showed the importance of two specific psychosocial work characteristics - employment contract and the internet access - in the explanation of satisfaction and self-rated health measures in seafarers. More precisely, job and life satisfaction levels were higher for shorter duration on board, favourable ratio of work to non-work days, and compliance with the contract regarding the changes in work and non-work days (regular shifts). Mental health was, on average, higher for shorter contracts and regular shifts. Of the two physical-health measures, only gastrointestinal symptoms were affected by the contract characteristics. The level of gastrointestinal symptoms was lower in those seafarers with shorter duration on board, and in those working in regular shifts. Both measures of physical health differed with regard to the internet access. Lower levels of gastrointestinal and cardiovascular symptoms were found in seafarers who have free, unlimited internet access on board. Although not all, our hypotheses were largely confirmed. Surprisingly, although on the basis of the qualitative study (12) we expected that the internet accessibility would have significant effects on satisfaction measures, these effects trailed.

In interpreting the results obtained we have to bear in mind that our design was cross-sectional, so it is not possible to draw causal conclusions from it. For example, self-rated health measures are largely affected by other factors besides the tested work characteristics, such as lifestyle factors (14, $15)$. Furthermore, it is possible that some other work characteristic which we did not include relates to the tested characteristics of the employment contract and/or internet accessibility, so higher satisfaction and better health status may be the consequences of some other favourable characteristic(s) of the shipping work environment (e.g. better organisation of work on board, i.e. fewer working and more resting hours, more favourable opportunities for physical and social activities, healthier food on board, etc.). A further limitation of our cross-sectional design is a possible underestimation of satisfaction and health levels due to the healthy worker effect.

Another possible threat to the validity of the data stems from the fact that we could not monitor the identities and truthfulness of participants in our online survey. However, we do not have any reason to believe that our data was flawed in any way. Studies which compare traditional (paper-and-pencil) and online surveys have shown that the results obtained by internet surveys do not appear to be tainted by false data or repeat responders, and they are, so far, consistent with results from traditional methods (35, 36). Still, our data may suffer from the general disadvantages of self-report measures, such as social-desirability bias and unwillingness to reveal private details about one's feelings or attitudes regarding the job. However, we believe that, with the anonymous procedure for participating in the online survey, and with instructions and explanation relating to the study procedure being obtained from a neutral researcher, these effects should be minimised. On the other hand, it still might be possible that participants have overstated their self-reports in some direction. Furthermore, it should be emphasised that the self-reported measures of gastrointestinal and cardiovascular symptoms assess only some of the symptoms that are included in the used scales, which of course does not imply an objective diagnosis of gastrointestinal or cardiovascular disease. Further research should therefore check the associations found in this study

Table 9 Effects of different aspects of contract and internet access on cardiovascular symptoms

\begin{tabular}{|c|c|c|c|c|c|c|c|}
\hline & & Mean & SD & df1 / df2 & Levene (p) & $F(p)$ & Welch (p) \\
\hline \multirow{4}{*}{$\begin{array}{l}\text { Time on board } \\
\text { (months) }\end{array}$} & 2 & 10.45 & 2.50 & \multirow{4}{*}{$3 / 294$} & \multirow{4}{*}{$\begin{array}{c}6.08 \\
(0.001)^{* *}\end{array}$} & & \multirow{4}{*}{$\begin{array}{c}0.63 \\
(0.597)\end{array}$} \\
\hline & 3 & 11.09 & 3.37 & & & & \\
\hline & 4 & 10.95 & 3.64 & & & & \\
\hline & $>4$ & 12.00 & 4.60 & & & & \\
\hline \multirow{2}{*}{$\begin{array}{l}\text { Ratio between } \\
\text { working and free } \\
\text { days }\end{array}$} & Favourable $(=)$ & 10.91 & 3.33 & \multirow{2}{*}{$1 / 296$} & \multirow{2}{*}{$1.71(0.192)$} & \multirow{2}{*}{$\begin{array}{c}0.48 \\
(0.488)\end{array}$} & \\
\hline & Unfavourable $(\neq)$ & 11.27 & 3.80 & & & & \\
\hline \multirow{2}{*}{$\begin{array}{l}\text { Compliance with } \\
\text { the contract }\end{array}$} & Regular shifts & 10.86 & 3.30 & \multirow{2}{*}{$1 / 296$} & \multirow{2}{*}{$2.56(0.110)$} & 2.24 & \\
\hline & Irregular shifts & 11.70 & 4.14 & & & $(.136)$ & \\
\hline \multirow{2}{*}{$\begin{array}{l}\text { Free unlimited } \\
\text { internet access }\end{array}$} & No & 11.53 & 3.72 & \multirow{2}{*}{$1 / 296$} & \multirow{2}{*}{$2.16(0.143)$} & \multirow{2}{*}{$\begin{array}{c}4.79 \\
(0.029)^{*}\end{array}$} & \\
\hline & Yes & 10.65 & 3.29 & & & & \\
\hline
\end{tabular}

Note: $* p<.05 ; * * p<.01$ 
by using objective parameters of health. Finally, the lack of data on the response rate, and the questionable representativeness of the target population, explained in the Method section, may also be an important limitation. More precisely, since the study relied on voluntary participation, the data may be biased, but we cannot test whether there is any systematic difference between our participants and non-participants.

In spite of the limitations noted, our design also had some advantages. Although the homogeneity of our sample (Croatian officers employed on cargo ships) limits the external validity, i.e. generalisability of our findings, we consider it an advantage which improves the internal validity, since we have avoided possible confounding effects of culture/nation, rank, and type of maritime activity. Further, we consider our total $\mathrm{N}$ to be relatively large, while considering seafarers a hard-to-reach population (7). Finally, we included only those seafarers who had been with the same company for a minimum of two years, since we believed that some duration was needed to be able to test the effects of work characteristics on the outcome measures. However, in spite of the rational reasons for this decision, in this way we avoided seafarers who had left their previous company (within the previous two years) for some reason. Unfavourable characteristics of the work contract and internet non-accessibility might be among their reasons.

\section{Conclusions and practical implications}

To our knowledge, this was the first study which tested the effects of different characteristics of the employment contract and internet accessibility on different measures of satisfaction and health of seafarers.

In spite of the fact that the significant effects obtained only show relations between more favourable work environments, in respect of the contract and internet accessibility and satisfaction and health measures, we consider these relations very important. Living and working in an isolated environment for lengthy periods of time, especially in situations of not knowing for sure when one will go home, and without internet accessibility, may act as strong psychosocial stressors in seafarers. Although the mechanisms of relations between a stressful environment and well-being and health measures may be explained by some other untested characteristic of the work environment, or by mediator variables, such as maladaptive coping strategies related to an unhealthy life style (15), or personal hardiness (7), this does not diminish the importance of the obtained associations. In fact, the results of this study can be considered a strong starting point for further research in the field, which should verify the associations obtained in this study by using more objective measures and representative samples.

Considering all mentioned limitations of this crosssectional study, the practical implication that can be given on the basis of the obtained results is that in promoting satisfaction and health in seafaring, attention should be given to reducing on-board duration, compliance with the contract regarding working and non-working days, and internet accessibility on board. This primarily relates to managers of shipping companies who should be aware of the importance of work environments, in respect of the contract and internet accessibility, for seafarers' satisfaction and health. Reducing long on-board duration and improving regularity of shifts, as well as providing free and unlimited internet access on board, as primary level interventions of occupational stress management may be important for the overall satisfaction and health in seafarers. From the organisational perspective, promoting work-related wellbeing and health of seafarers may also have important repercussions for retention of seafarers and minimising organizational costs of turnover.

\section{Acknowledgements}

We thank all the seafarers who participated in this study. Furthermore, we are grateful to all individuals and the organisations (specified in the Methods) that helped us to conduct and/or advertise our study.

\section{Funding}

None.

\section{Ethical approval}

The study was approved by the Ethical Committee of the Department of Psychology, University in Zadar.

\section{Declaration of authorship}

$\mathrm{AS}$ and ZP contributed to the conception and design of the study, and to data acquisition. AS contributed to data analysis and to interpretation of data. AS and ZP drafted the manuscript.

\section{Competing interests}

Authors declare: no support from any organisation for the submitted work; no financial relationships with any organisations that might have an interest in the submitted work; no other relationships or activities that could appear to have influenced the submitted work.

\section{REFERENCES}

1. Oldenburg M, Jensen HJ, Latza U, Baur X. Seafaring stressors aboard merchant and passenger ships. Int J Public Health 2009;54:96-105. doi:10.1007/s00038-009-7067-z

2. Oldenburg M, Baur X, Schlaich C. Occupational risks and challenges of seafaring. J Occup Health 2010;52:249-56. doi: 10.1539/joh.k10004

3. Roberts SE. Work related mortality from gastrointestinal diseases and alcohol among seafarers employed in British 
merchant shipping from 1939 to 2002. Int Marit Health 2005;56:29-47. PMID: 16532583

4. Roberts SE, Jaremin B. Cardiovascular disease mortality in British merchant shipping and among British seafarers ashore in Britain. Int Marit Health 2010;62:107-16. PMID: 21154296

5. Oldenburg M, Baur X, Schlaich C. Cardiovascular diseases in the modern maritime industry. Int Marit Health 2010;62:101-6. PMID: 21154295

6. Iversen RTB. The mental health of seafarers. Int Marit Health 2012;63:78-89. PMID: 22972547

7. Doyle N, MacLachlan M, Fraser A, Stilz R, Lismont K, Cox $\mathrm{H}, \mathrm{McVeigh} \mathrm{J}$. Resilience and well-being amongst seafarers: cross-sectional study of crew across 51 ships. Int Arch Occup Environ Health 2016;89:199-209. doi: 10.1007/s00420-0151063-9

8. Alderton T, Bloor M, Kahveci E, Lane T, Sampson H, Thomas M, Winchester N, Wu B, Zhao M. The Global Seafarer: Living and Working Conditions in a Globalized Industry. Geneva: International Labour Organization; 2004.

9. Carotenuto A, Molino I, Fasanaro AM, Amenta F. Psychological stress in seafarers: a review. Int Marit Health 2012;63:188-94. PMID: 24595974

10. MacLachlan M, Kavanagh B, Kay A. Maritime health: a review with suggestions for research. Int Marit Health 2012;63:1-6. PMID: 22669806

11. MacLachlan M, Cromie S, Liston P, Kavanagh B, Kay A. Psychosocial and organisational aspects. In: Carter T, editor. Textbook of maritime medicine, 2013 [displayed 12 October 2016]. Available at http://textbook.ncmm.no/index.php/ textbook-of-maritime-medicine

12. Slišković A, Penezić Z. Descriptive study of job satisfaction and job dissatisfaction in a sample of Croatian seafarers. Int Marit Health 2015;66:97-105. doi: 10.5603/imh.2015.0023

13. Carter T, Jepsen JR. Exposures and health effects at sea: report on the NIVA course: Maritime Occupational Medicine, Exposures and Health Effects at Sea Elsinore, Denmark, May 2014. Int Marit Health 2014;65:114-21. doi: 10.5603/ imh.2014.0024

14. Dahl E. Gastrointestinal diseases. In: Carter T, editor. Textbook of maritime medicine, 2013 [displayed 12 October 2016]. Available at http://textbook.ncmm.no/index.php/ textbook-of-maritime-medicine

15. Oldenburg M. Risk of cardiovascular diseases in seafarers. Int Marit Health 2014;65:53-7. doi: 10.5603/imh.2014.0012

16. Slišković A. Shiftwork problems. Arh Hig Rada Toksikol 2010;61:465-77. doi: 10.2478/10004-1254-61-2010-2036

17. Tang L. Waiting together: Seafarer-partners in cyberspace. Time Society 2012;21:223-40. doi: 10.1177/0961463x 10387690

18. Papachristou A, Stantchev D, Theotokas I. The role of communication to the retention of seafarers in the profession. WMU J Marit Affairs 2015;14:159-76. doi: 10.1007/s13437015-0085-1

19. Chrousos GP. Stress and disorders of the stress system. Nat Rev Endocrinol 2009;5:374-81. doi: 10.1038/nrendo.2009.106

20. Carotenuto A, Fasanaro AM, Molino I, Sibilio F, Saturnino A, Traini E, Amenta F. The Psychological General WellBeing Index (PGWBI) for assessing stress of seafarers on board merchant ships. Int Marit Health 2013;64:215-20. doi: 10.5603/imh.2013.0007

21. Jensen OC, Sørensen JFL, Thomas M, Canals ML, Nikolic $\mathrm{N}, \mathrm{Hu}$ Y. Working conditions in international seafaring. Occup Med 2006;56:393-7. doi: 10.1093/occmed/kq1038

22. Juozulynas A, Sąlyga J, Malakauskiene R, Lukšiene A. Physical and psychological dimensions of health-related quality of life among Lithuanian seamen. Acta Med Lituan 2007;14:50-3.

23. Marinov E, Maglić L, Bukša J. Market competitiveness of Croatian seafarers. Sci J Marit Res 2015;29:64-8.

24. Zorović M. Assessment of Croatian manpower - what can they offer? $16^{\text {th }}$ European Manning and Training Conference, 2013 [displayed 12 October 2016]. Available At http://www. zorovic.hr/data/public/documents/manning_training_ dubrovnik_2013__mario_zorovic.pdf

25. Judge TA, Parker SK, Colbert AE, Heller D, Ilies R. Job satisfaction: A cross-cultural review. In: Anderson N, Ones DS, Sinangil HK, Viswesvaran C, editors. Handbook of industrial, work, and organizational psychology. Vol 2, Organizational psychology. London: Sage; 2001. p. 25-52.

26. Diener E, Emmons RA, Larsen RJ, Griffin S. The Satisfaction with Life Scale. J Pers Assess 1985;49:71-5. doi: 10.1207/ s15327752jpa4901_13

27. Pavot WG, Diener E, Colvin CR, Sandvik E. Further validation of the Satisfaction with Life Scale: Evidence for the cross-method convergence of well-being measures. J Pers Assess 1991;57:149-61. doi: 10.1207/s15327752 jpa5701_17

28. Pavot, WG, Diener E. Review of the Satisfaction with Life Scale. Psychol Assess 1993;5:164-72. doi: 10.1037//10403590.5.2.164

29. Kobau R, Sniezek J, Zack MM, Lucas RE, Burns A. Wellbeing assessment: An evaluation of well-being scales for public health and population estimates of well-being among US adults. Appl Psychol Health Well-Being 2010;2:272-97. doi: 10.1111/j.1758-0854.2010.01035.x

30. Berwick DM, Murphy JM, Goldman PA, Ware JE Jr, Barsky AJ, Weinstein MC. Performance of a five-item mental health screening test. Med Care 1991;29:169-76. doi: 10.1097/00005650-199102000-00008

31. Barton J, Spelten E, Totterdell P, Smith L, Folkard S, Costa G. The Standard Shiftwork Index: a battery of questionnaires for assessing shiftwork-related problems. Work Stress 1995;9:4-30. doi: 10.1080/02678379 508251582

32. Schmider E, Ziegler M, Danay E, Beyer L, Bühner M. Is it really robust? Reinvestigating the robustness of ANOVA against violations of the normal distribution assumption. Meth Eur J Res Meth Behav Soc Sci 2010;6:147-51. doi: 10.1027/1614-2241/a000016

33. Howell DC. Statistical Methods for Psychology. $6^{\text {th }}$ ed, Belmont (CA): Thomson Wadsworth; 2007.

34. Tabachnick BG, Fidell LS. Using Multivariate Statistics. $5^{\text {th }}$ ed, Needham Heights (MA): Allyn and Bacon, Inc.; 2007.

35. Gosling SD, Vazire S, Srivastava S, John OP. Should we trust web-based studies? A comparative analysis of six preconceptions about internet questionnaires. Am Psychol 2004;59:93-104. doi: 10.1037/0003-066x.59.2.93

36. Gosling SD, Mason W. Internet research in psychology. Annu Rev Psychol 2015;66:877-902. doi: 10.1146/annurevpsych-010814-015321 


\section{Provjera povezanosti različitih aspekata ugovora i dostupnosti interneta na brodu sa zadovoljstvom poslom i životom te zdravljem pomoraca}

Cilj ovoga istraživanja bio je provjeriti povezanosti između različitih aspekata ugovora i dostupnosti interneta na brodu sa zadovoljstvom i zdravljem pomoraca. Online upitnik ispunilo je 298 hrvatskih pomoraca časničkoga ranga, zaposlenih na teretnim brodovima s radnim iskustvom u trenutačnoj radnoj organizaciji od najmanje dvije godine. Upitnik je uz pitanja o osnovnim socio-demografskim karakteristikama uključivao pitanja vezana za radni ugovor i dostupnost interneta na brodu te mjere zadovoljstva poslom, zadovoljstva životom, psihičkog zdravlja, gastrointestinalnih i kardiovaskularnih simptoma. Prosječne razine zadovoljstva poslom i životom bile su veće kod kraćih ugovornih razdoblja na brodu, povoljnijeg omjera radnih i neradnih dana te poštovanja ugovora u pogledu izmjena radnih i neradnih dana. Razina psihičkoga zdravlja razlikovala se u istom smjeru, ali samo za dva aspekta ugovora: dužinu razdoblja na brodu i poštovanje ugovora. Razina gastrointestinalnih simptoma bila je manja kod pomoraca koji su na brodu provodili kraća razdoblja i kod kojih je poštovan ugovor te kod pomoraca s neograničenim pristupom internetu na brodu, kod kojih je utvrđena $\mathrm{i}$ niža razina kardiovaskularnih simptoma. U promicanju zadovoljstva i zdravlja pomoraca pažnja bi se trebala usmjeriti na smanjivanje ugovornih razdoblja na brodu, poštovanje ugovora te poboljšavanje dostupnosti interneta na brodu.

KLJUČNE RIJEČI: gastrointestinalni i kardiovaskularni simptomi; izolirano radno okruženje; omjer radnih i neradnih dana; poštovanje ugovora; psihičko zdravlje; ugovorno razdoblje na brodu 


\section{ANNEX: QUESTIONNAIRE}

Please answer the following questions related to your demographic and work characteristics as accurately as possible.

Gender: Male / Female

Age (years)

Service length in maritime sector (years)

Service length in current shipping organisation (years)

Education level: 1) High school, 2) College, 3) University

Job description: 1) Engine Officer, 2) Deck Officer, 3) Chief engineer, 4) Commander

Type of cargo ship: 1) General cargo, 2) Tankers (oil and oil products), 3) Bulk cargo, 4) Containers, 5) LNG and LPG, 6) Chemicals, 7) Ro-Ro (cargo on wheels), 8) Combined cargo

Shipping organisation: 1) Croatian, 2) Foreign

Marital status: 1) Single, 2) Married / in domestic partnership

Children (number)

Current location: 1) On-board, 2) At home

On-board stay according to contract: 1, 2, 3, 4, 5, 6, more than 6 months

Home stay according to contract: 1, 2, 3, 4, 5, 6, more than 6 months

Compliance with contract regarding changes to ship and home periods: $1=$ always in compliance with contract; $2=$ mostly in compliance with contract; $3=$ mostly not in compliance with contract; $4=$ never in compliance with contract Having free and unlimited access to the internet on board: 1) Yes, 2) No

The following items relate to your evaluation of your life and job. Using the scale below, indicate your level of agreement with each item by ticking the appropriate number.

$1=$ strongly disagree; $2=$ mostly disagree;

$3=$ neither agree nor disagree; $4=$ mostly agree;

$5=$ strongly agree

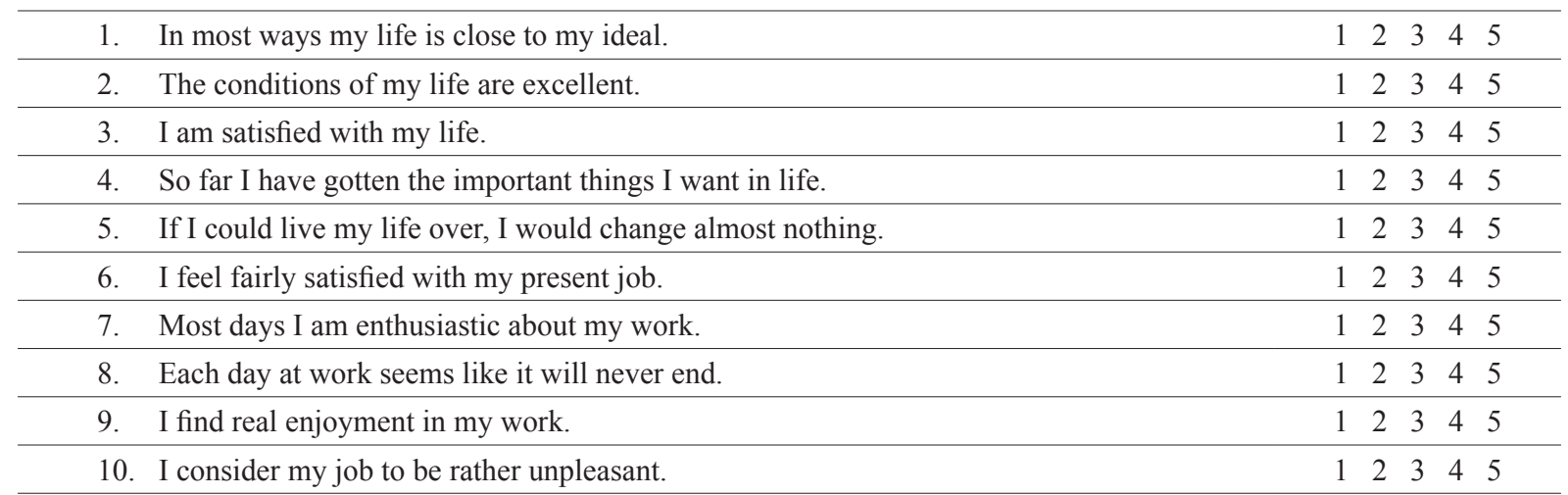

For each following question indicate the number on the scale that best describes you during the past month.

$1=$ all of the time; $2=$ most of the time;

$3=$ a good bit of the time; $4=$ some of the time;

$5=$ a little of the time; $6=$ none of the time / never

\begin{tabular}{rrr}
\hline How much of the time have you... & \\
\hline $1 . \quad$.. been a very nervous or anxious person? & 123456 \\
\hline $2 . \quad$... felt calm or peaceful? & 123456 \\
\hline $3 . \quad$... been a happy person? & 123456 \\
\hline $4 . \quad$.. felt downhearted or blue? & 123456 \\
\hline $5 . \quad$... felt so down in the dumps that nothing could cheer you up? & 123456 \\
\hline
\end{tabular}


Please answer the following questions by indicating the appropriate number.

$1=$ almost never; 2 =quite seldom;

3=quite often; $4=$ almost always

\begin{tabular}{|c|c|c|c|c|c|}
\hline How ofte & $n \ldots$ & & & & \\
\hline 1. & ... is your appetite disturbed? & 1 & 2 & 3 & 4 \\
\hline 2. & ... do you have to watch what you eat to avoid stomach upsets? & 1 & 2 & 3 & 4 \\
\hline 3. & ... do you feel nauseous? & 1 & 2 & 3 & 4 \\
\hline 4. & ... do you suffer from heartburn or stomach-ache? & 1 & 2 & 3 & 4 \\
\hline 5. & ... do you complain of digestion difficulties? & 1 & 2 & 3 & 4 \\
\hline 6. & ... do you suffer from bloated stomach or flatulence? & 1 & 2 & 3 & 4 \\
\hline 7. & ... do you suffer from pain in your abdomen? & 1 & 2 & 3 & 4 \\
\hline 8. & ... do you suffer from constipation or diarrhoea? & 1 & 2 & 3 & 4 \\
\hline 9. & ... do you suffer from heart palpitations? & 1 & 2 & 3 & 4 \\
\hline 10. & ... do you suffer from aches and pains in your chest? & 1 & 2 & 3 & 4 \\
\hline 11. & ... do you suffer from dizziness? & 1 & 2 & 3 & 4 \\
\hline 12. & ... do you suffer from sudden rushes of blood to your head? & 1 & 2 & 3 & 4 \\
\hline 13. & ... do you suffer from shortness of breath when climbing the stairs normally? & 1 & 2 & 3 & 4 \\
\hline 14. & ... have you been told that you have high blood pressure? & 1 & 2 & 3 & 4 \\
\hline 15. & ... have you been aware of your heart beating irregularly? & 1 & 2 & 3 & 4 \\
\hline 16. & ... do you feel "tight" in your chest? & 1 & 2 & 3 & 4 \\
\hline
\end{tabular}

